Article

\title{
'It's a Matter of Life or Death': Jewish Migration and Dispossession of Palestinians in Acre
}

\author{
Amandine Desille ${ }^{1}$ and Yara Sa'di-Ibraheem ${ }^{2, *}$ \\ ${ }^{1}$ Institute of Geography and Spatial Planning, University of Lisbon, 1600-276 Lisbon, Portugal; \\ E-Mail: amandine.desille@campus.ul.pt \\ 2 Department of Geography and the Human Environment, Tel-Aviv University, 69978 Tel-Aviv, Israel; \\ E-Mail: yarasadi@gmail.com \\ * Corresponding author
}

Submitted: 25 September 2020 | Accepted: 5 November 2020 | Published: 27 April 2021

\begin{abstract}
In this article, we aim to identify the actors and unpack the discourses and administrative practices used to increase current mobilities of people (Jewish immigrants, investors, tourist visitors, and evicted residents) and explore their impact on the continuity of the settler-colonial regime in pre-1948 Palestinian urban spaces which became part of Israel. To render these dynamics visible, we explore the case of Acre-a pre-1948 Palestinian city located in the north-west of Israel which during the last three decades has been receiving about one hundred Jewish immigrant families annually. Our findings reveal a dramatic change in the attempts to judaise the city: Mobility policies through neoliberal means have not only been instrumental in continuing the processes of displacement and dispossession of the Palestinians in this so-called 'mixed city,' but have also recruited new actors and created new techniques and opportunities to accelerate the judaisation of the few Palestinian spaces left. Moreover, these new mobility policies normalise judaisation of the city, both academically and practically, through globally trendy paradigms and discourses. Reframing migration-led development processes in cities within a settler-colonialism approach enables us to break free from post-colonial analytical frameworks and re-centre the native-settler relations as well as the immigrants-settlers' role in territorial control and displacement of the natives in the neoliberal era.
\end{abstract}

\section{Keywords}

Acre; Israel; migration; neoliberalism; Palestine; settler colonialism; urban development

\section{Issue}

This article is part of the issue "Migration-Led Institutional Change in Urban Development and Planning" edited by Robert Barbarino (TU Dortmund University, Germany), Charlotte Räuchle (Free University Berlin, Germany) and Wolfgang Scholz (TU Dortmund University, Germany).

(C) 2021 by the authors; licensee Cogitatio (Lisbon, Portugal). This article is licensed under a Creative Commons Attribution 4.0 International License (CC BY).

\section{Introducing Settler Colonialism and Migration-Led Urban Transformations in Israel}

In the last few decades, considerable research revealed how settler-colonial cities are being portrayed as modern, globalised places, and "a magnet for international migration," as means to conceal their on-going colonial nature (Porter \& Yiftachel, 2019, p. 178). Other scholars have emphasised that neoliberal discourses and prac- tices do not only conceal colonial structures but also take part in processes which result in eliminating the natives (Coulthard, 2014). Yet, urban research has traced colonial processes in neoliberal Israel only very recently, and mostly concerning land and property privatisation processes (Fenster, 2019; Porter \& Yiftachel, 2019; Yacobi \& Tzfadia, 2017).

When it comes to immigration matters, the Law of Return (1950, amended in 1976) allows the immi- 
gration of individuals of Jewish descent and is usually conceived as yet another national migration policy, or, when analysed more critically, as an ethnonational repatriation policy similar to those of Germany. Palestinian refugees, in turn, are still denied their 'right to return' (Khalidi, 1992). Migration studies scholars working on Israel have focused mostly on the issues of incorporation of new Jewish immigrants (Amit, 2009; Haberfeld, Semyonov, \& Cohen, 2000; Lewin-Epstein, Semyonov, Kogan, \& Wanner, 2003; Mesch, 2002; Tubergen, Maas, \& Flap, 2004), immigration and spatial/urban transformations (Auerbach, 2011; Berthomière, 2003; Lipshitz, 1998; Tzfadia \& Yacobi, 2007, 2011; Yiftachel \& Tzfadia, 2004), and intra-community racialisation. This last point refers to the large scientific production on internal racialisation in Israel, or the post-colonial stratification between Jews of European descent-Ashkenazim-and Jews of African and Asian descent-Mizrahim-(see Chetrit, 2000; Shenhav, 2006; Yiftachel, 2000). This more recent strand includes the racialisation of Former Soviet Union (FSU) immigrants (Golden, 2001; Lerner, 2015; Remennick, 2002), Ethiopian immigrants, and asylum seekers (Elias \& Kemp, 2010). To the best of our knowledge, very little has been written on the racial stratification of the society at large-between different Arab groups, Jewish groups, and non-Israelis (with the exception of Samman [2013] and Dorchin \& Djerrahian [2020]). We argue that on the one hand, on-going Jewish immigration is still discussed within post-colonial frameworkshence ignoring the on-going colonisation processes; on the second hand, it is discussed through neoliberal concepts and tools, including the participation of new private actors.

The implications of such post-colonial approaches are many. Firstly, it institutes the starting point for migration studies in Israel with the establishment of Israel in 1948. This temporality allows scholars to emphasise intra-community racism and marginalise the fact that settler-migrants were instrumental to territorial occupation and Palestinians' displacement before and after 1948. Post-colonial approaches have also contributed to normalisation: The diversification of migration experiences has pointed towards the convergence of Israel with other industrialised countries' experiences, in line with Israel's great efforts to preserve its image as a 'multicultural' modern liberal democracy (Amoruso, Pappé, \& Richter-Devroe, 2019). If some of these latter works address processes of demographic engineering in Israel, they dissociate the impact on Palestinians both in Israel and in the West Bank.

Secondly, the post-colonial approach relies on a Euro-centred analytical framework (Hugill, 2017). The analysis of discourses, policies, and practices related to so-called Aliyah (Hebrew term meaning 'ascent' referring to Jewish immigration) or to new migration types shows a shift in the conception of Jewish immigration in the last decades from an act of settling and colonising to a 'normalised' act of migration, discussed in the neolib- eral terms of 'diversity,' 'multiculturalism,' 'pluralism,' 'mixed cities,' and more. Yet, these discussions fall short of adding that neoliberalisation and settler colonialism are mutually constitutive.

Hence, rather than using the post-colonial approach, which implies having overcome the colonial condition (Veracini, 2010, p. 42), the settler-colonial framework brings forth migration as an on-going structure for the dispossession of the Palestinians (Sayegh, 1965; Wolfe, 2006). Following settler-colonial logic, the heterogeneity of the settler space is not a proof of multiculturalism or pluralism, but rather it is a demographic engineering technique used to maintain the settlers' society. For example, Svirsky and Ben-Arie (2017) emphasise how the shared life of the natives in Palestine, both Palestinians and Jews, before the third decade of the twentieth century, was destroyed by Zionism to enable the emergence of the settlers' society racial division. Moreover, some immigrants 'Exogenous Other,' namely the racialised (Mizrahim or Black) Jewish groups, remain excluded from the settler society (Veracini, 2010, p. 26). Arguably, normalising the immigration experiences through the post-colonial framework and neoliberal terms participates in a politics of knowledge: One should question the socio-political implications of the use of European migration analytical tools in the Israeli-Palestinian context.

To shed light on how the settler colonial structure frames migration-led urban transformations in Israel, we will analyse the case of Acre, a pre-1948 Palestinian city located in the northwest of Israel, in which only $2 \%$ of the pre-1948 community remained. In line with Israeli immigration history, Acre's demographic composition is strongly related to the different layers of Jewish migration: Jews from Middle Eastern countries, followed by North African Jews after statehood; and in the 1970s, Soviet Jews, followed in 1990s by FSU immigrants, including a large group from Azerbaijan. Since the 1990s, the city has actively reached out to Jewish candidates to immigration and receives about 100 new families of Jewish immigrants every year, including from Ukraine, France, or India. As we will show in this article, Acre's demographic composition is expressed officially through terms reflecting pluralism. It is also the discourse used by non-institutional actors, especially in tourism and urban renewal. Nevertheless, Palestinian inhabitants of Acre still claim that displacement practices are on-going and shift the focus back to the native-settler power relations.

Hence, in this article, we argue that neoliberalisation processes have not only been instrumental to maintain the processes of displacement and dispossession of the Palestinians in Acre and beyond in Israel but have also (re)produced techniques and opportunities to accelerate the judaisation of the few Palestinian spaces left. Moreover, it has also recruited new actors beside State actors, whose role we will explain further. To do so, we examine two levels: the official ideological level, represented by the State on the one hand; and the changes observed at the city level on the other hand. 


\section{City-Level Policymaking and Settler Colonialism}

A major development in migration scholarship, highly addressed by this thematic issue, is that of the role of actors located in cities. Against 'methodological nationalism,' scholars have proposed to analyse the city level to understand new migration and urban-related policy developments. Among them, those affiliated with the discipline of geography and urban studies have made three important contributions. Firstly, they acknowledge a double movement, creating tension between "the urban dimensions of rescaled migration processes" and "the role of migration in the on-going rescaling of urban spaces" (Brenner, 2010, p. 24). Secondly, they point to a "partial, incomplete and contingent devolution" of immigration power to the local state (Varsanyi, 2008, p. 882), rarely accompanied by the necessary funds (Ellis, 2006). In the case of Israel, we will see that local immigration policies are a voluntary domain (Razin, 2003) which requires from local actors an application to public funds, independently of the distribution of immigrants in the various cities of the country. Thirdly, the interventions of social actors in the local turn are meaningful (Glick Schiller \& Çağlar, 2010), enabling us to reconcile structural considerations with the agency of actors.

To reflect on these changes, migration scholars have proposed the concept of 'decoupling' (Scholten \& Penninx, 2016, p. 976), a process by which "in a single policy domain, there may be policies at different levels that are dissociated and may even be contradictory" (Scholten cited in Oomen, 2019, p. 5). Oomen (2019, p. 4) further proposes to "focus on the dynamics of decoupling, the processes by which cities disengage from national policies to take their own positions toward refugee and migrant reception and integration." We recognise the importance of escaping methodological nationalism, yet we find that decoupling does not necessarily lead to more accommodating immigration policies, nor that it enables to acknowledge the shift of settler colonialism towards the city level. This piece might therefore come as a counterpoint to the thematic issue's contributions, since it proposes that migration-led urban development and neoliberal policies can be used to produce a hostile environment, act as a veil to hide structural violence against the natives in the colonial context, and have dramatic effects on the existing community.

Moreover, not all actors in cities can make substantial changes. As Lacroix (2018) has argued, the autonomy granted to local governments in many parts of the world may lead to paradoxical outcomes. For some, decentralisation policies have increased the dependence of local governments towards external actors, including private actors, international organisations, and the central administration. Indeed, due to the lack of resources, the autonomy of Acre is often compromised, leading to competition over legitimacy and budget within the municipality itself, leaving some areas untreated, while others suffer from overlapping. But it is also threatened by privatisation as new private actors including industrials, diaspora organisations, messianic settlers, etc. have penetrated the field of Jewish immigration policy (Desille, 2019). This piece explores the impact of these shifts on the settler-colonial structure.

\section{Setting the Stage: Acre, Immigration, and Urban Development}

Before we turn to contemporary considerations regarding immigration and urban development in Acre, it is worth coming back to some historical elements which unveil the structural violence against the Palestinians. Acre is endowed with a rich Arab, Islamic, and World history, which led to its recognition as a UNESCO World Heritage site in 2001 . The city does not have a religious affinity to Judaism and the presence of local Jews in the city was limited to a tiny community which left the city following the outbreak of the 1936 Palestine revolt against the British Mandate (Torstrick, 2000, pp. 43, 53). Before the 1948 War, Acre had a population of 15,500, all of whom were Palestinians (Torstrick, 2000, p. 52).

On 18 May 1948, the city was occupied by the main Jewish militia Hagana and became part of Israel (Abbasi, 2010). Only 3,100 Palestinians were counted in the city at the end of 1948, of which about 1,000 were refugees displaced from adjacent places (Paz, 1998, pp. 95-134). They were forcibly concentrated in the old quarter of the city and were subjected to a military rule until 1951 (Torstrick, 2000, p. 64). Embodying a 'state of exception,' the military government functioned according to emergency regulations, in which Palestinian inhabitants were quarantined in the old quarter. This 'rule of man over man,' to use Scmitt's lexicon (Sa'di, 2016, pp. 6-7), was marked by looting and many acts of cruelty (Torstrick, 2000 , p. 56). Additionally, in 1950, buildings belonging to refugees (which included 638 commercial places and 5528 residential rooms) were seized first by the management of the 'Custodian of Absentees' Property,' then by the 'Development Authority,' both operating under the auspices of the Ministry of Finance (Fischbach, 2003, p. 30). The Development Authority had the warrant to sell, up to a certain amount, urban refugees' properties in the private sector. Until then, they were managed by governmental companies such as the rent-controlled housing company Amidar, which is owned, among others, by the Jewish Agency (50\%), the Jewish National Fund (20\%), and the State of Israel (20\%).

Today, Acre is located in the north of Israel, $20 \mathrm{~km}$ from the Lebanese border. According to the last publication of the Israel Central Bureau of Statistics (2015), Acre ranks $4 / 10$ in terms of peripheral indicator (10 being Tel Aviv area) and 4/10 when it comes to socioeconomic indicator (10 being the richest localities), low indicators placing Acre at the periphery. Acre has 48,303 inhabitants, 15,361 of whom are Palestinians. The Palestinian inhabitants constitute a deprived minority and are located at the bottom of the socio-economic 
and educational scales. Their bulk continues to live in the old quarter inside the historic walls. The buildings in this quarter date to the eighteenth century and form the main tourist attraction of the city. It includes some Ottoman Islamic sites such as Al-Jazzar mosque and Khan al-Umdan as well as some underground sites of the remains of the Crusader period. While the touristic buildings are being preserved, the infrastructure and the houses managed by Amidar are in poor condition due to negligence. Since the end of the military government, some Palestinians families were able to move out of the old quarter to more modern areas, either built during the British Mandate or in the 1960s and 1970s for Jewish immigrants.

Israeli post-colonial scholarship and the official discourse categorise Acre as a 'mixed city' to capture the multiplicity of socio-economic, political, and ethnic cleavages that exist within its domain. However, as various scholars argue, this category is misleading and normalises the native-settler relations in the city (Falah, Hoy, \& Sarker, 2000; Tzfadia, 2011; Yacobi, 2009). In fact, the aim of urban development and migration policies exceeds ethnic segregation to pursue judaisation processes which aim to displace Palestinians. A case in point: Acre municipal plans in the 1980 s aiming to move Palestinian families outside Acre by securing decent housing for them in the village of Makr. According to Torstrick (2000, p. 81), a report by the municipality issued in 1985 to the government discussed the 'Arab sector' problems in Acre including housing, poverty, and crowdedness. The "report noted that the municipality was concentrating its efforts on moving families with many children to Makr" (Torstrick, 2000, p. 81).

In addition to the spatial containment of Palestinians in selected neighbourhoods, demographic engineering also occurs through Jewish immigration outreach and active settlement policies. Today, the promotion of immigration in Israeli cities is enabled through outreach programmes (termed idud aliyah or encouragement of migration) on the one hand; and specialised municipal units or departments on the other hand. For this endeavour, the municipality of Acre participates in the national programme 'Group Aliyah,' a joint program of the Ministry of Immigration and Absorption (MOIA), the Jewish Agency, and municipalities. Participation in the programme implies that municipalities should send a plan, including projections. The municipality receives the maximum support from MOIA, meaning that 3.5 fulltime jobs are dedicated to Jewish immigration and their settlement. According to a clerk at MOIA, interviewed in 2014, the main beneficiaries are cities in the periphery and cities hosting Palestinian residents. The deputy director of the municipal department dedicated to immigration issues is in daily contact with representatives of the Jewish Agency in the FSU mostly, to encourage candidates to immigrate to Acre. Municipal agents in this department ensure their adaptation to the city, from receiving entitlements, registering children at schools, learning Hebrew, retraining and even religious learning, and re-conversion to Orthodox Judaism. Other municipal departments are also involved, including welfare, education, and employment. The municipality receives funding for an 'Integration of Caucasus Jews' coordinator' due to the presence of an important community from Azerbaijan.

Non-State actors are also present to push forward the settlement of new immigrants, including messianic settlers such as Garin Torani ('seeds on duty') and ethnic NGOs. The intrusion of private actors in immigration matters has been a subject of research in European policies (Lahav, 1998). Yet, in Israel, it is still embryonic. Babis (2016) showcased the role of NGOs for Spanish-speaking immigrants, whereas Scioldo-Zürcher (2014 to 2017) led a research project at the French Research Centre in Jerusalem showing the increased role of French-speaking migration entrepreneurs in the settlement of French Jews, notably beyond the green line.

\section{Methodology}

To overcome the oppositional stances used to describe Acre-for some a mixed, non-segregated city; for others a city where two groups live two separate liveswe propose to juxtapose two sets of literature, but also two datasets generated by our research projects. We believe that this juxtaposition will enhance the dialogue between migration studies, refugee studies, internal displacement studies, settler colonialism literature, and geography. Between 2014 and 2019, we conducted 18 interviews with officials, municipal agents, and other stakeholders dealing with migration and tourism carried out in Hebrew and French, and with two Palestinian residents and activists carried out in Arabic and English. Besides the Mayor's, all names were modified for anonymity purposes. Institutional actors were informed of the research goals by email and at the beginning of each recorded interview. Additionally, after the interviews were conducted in the municipality, a report was written, giving the Mayor a chance to react to comments. We also collected secondary data in Hebrew and Arabic, such as news, posts on social networks, and governmental committee protocols. Moreover, we conducted fieldwork together in 2019 in the old city of Acre, where we met and discussed tourism development with five Palestinian and Jewish entrepreneurs and employees, in English and Arabic. On this occasion, we did not collect names or other details that would disclose the identity of the respondents.

We have based our methodology on 'grounded theory.' Usually associated with the work of Glaser and Strauss (1967), grounded theory corresponds to the 'discovery of theory from data.' This does not mean that each empirical study will lead to a new theory, but that data can challenge existing theories and enrich them. Later on, Charmaz (2011) lays down the various dimensions characterising a grounded theory approach: the 
rejection of claims of objectivity, the located character of knowledge (and therefore the variations and differences it implies), the co-construction of meanings, the impact of the interactions between researchers and participants, and the fundamental role of reflexivity. A crucial element highlighted by Charmaz $(2011$, p. 3 ) is the co-production of knowledge by the researchers and participants for their research, as "people construct both the studied phenomenon and the research process through their actions." Desille is a French national who lived several years in Israel and speaks Hebrew; while Sa'diIbraheem is a Palestinian citizen of Israel, proficient in Arabic, Hebrew, and English. We have discussed how narratives and information given to us differed depending on which one of us turned to participants, and in which language-Arabic, Hebrew, or English. By working together and confronting the literature we usually mobilise with both the dataset we collected and our position when engaging with residents of Acre, we aim to modestly bridge the gap between these 'separate lives.'

\section{Actors and Institutions in Acre: Neoliberal Means for Settler-Colonial Displacement}

\subsection{Immigration: Economic Development or Demographic Engineering?}

Demographic and social engineering through Jewish immigration outreach and active settlement policies have been at the core of settler colonialism in Israel. Even before statehood, Zionist organisations' immigration policy did not only restrict arrivals to Jews but also limited the immigration of 'penniless Jews' (Shilo, 1994). In her volume on Acre, Torstrick (2000, p. 58) mentions that the local leadership had advocated for the settlement of young, skilled professionals in Acre since the 1950s, which was very much in line with the national policy, assisting Jewish refugees on one hand; and encouraging the immigration of young professionals on the other. However, despite the officials being vocal, few young professionals were redirected to Acre.

In the last two to three decades, Acre has deployed a more aggressive policy towards Jewish immigration. Palestinian residents of Acre see such policies as increasing attempts to judaise the city, i.e., to make the identity of the space and community more Jewish. As Bilal, an interviewed Palestinian resident, states: "The Israeli capital started to leave Acre behind, for being a periphery, poor, and full of Arabs. This led Acre's identity to become more Arabic. Therefore, for [Mayor Lancry], it was important to bring Jews" (2019). The municipality, through its spokesperson, defensively rejects the 'judaisation' argument and presents immigration policies as a means to "bring a strong population" (extract from field diary, 2014). When interviewed, Mayor Lancry (2014) went even further, arguing that "immigrants are one of my daily priorities." He continued: "I see in immigrants a resource that can lead the city to social and economic development." This discourse is backed by the deputy director of the municipal immigration department, Elisa (2014), who translates the municipal needs through targeting candidates who are "educated people, with children," and whose "potential is usable." Zion (2015), the deputy mayor, himself an immigrant from the FSU, states: "The [immigrants], they are also, apart from the cultural and social issues, they also fill the schools." According to statistics, these goals are met, as between 2007 and 2011, 749 new immigrants settled in Acre, among them only $7.74 \%$ were older than 65 (Central Bureau of Statistics, 2012). But the age of the newcomers does not seem to be the most crucial criteria. When asked about the underlying motives of this immigration agenda, Zion finally revealed the racial aspect of this work: "It's life and death....All the (Palestinian) villages will come to us," he said. A statement that emphasises not only the racial categorisation among Acre's social groups but also his perspective regarding the possibilities of existing: us or them. He continued: "It's a matter of life or death. What did you think? They will take the school, they will. I tell you that. We, Aliyah integration, it's blood, blood transfusion." While this quote might be stating the obvious of the Zionist agenda, in the municipality's official statements, it is usually concealed by 'diversity' and 'multiculturalism' discourse, as we will show later. The terms used by the deputy mayor as "life or death" and "blood transfusion" reveal, on the one hand, the structural elimination of the natives in settler-colonial societies, and on the other hand, the settlers' continuous fear of the return of the natives.

Nevertheless, in recent decades, the municipality is not the only institution dealing with the settlement of new immigrants. A range of private actors has also entered the arena. For instance, a French magazine and real estate agents have joined forces to bring French Jewish families to Acre. As a result, a dozen French families settled in Acre. More recently, the non-profit organisation Shavei Israel, whose stated objective is "assisting descendants of Jews and the Lost Tribes of Israel to reclaim their roots" (Shavei Israel, n.d.) has participated in the settlement of Indian "Bnei Menashe" immigrants. They funded a position among the messianic settler group Garin Torani, present in the city of Acre to assist in the incorporation of these newcomers. Messianic settlers such as the Garin Torani are families and individuals who, according to their definition, organise to live together in towns and neighbourhoods with a small Jewish or religious population, to strengthen the connection to Judaism and drive social and economic change. For example, one group called Garin Daniali has been active in the last few years in mandatory Acre, and describes itself as a group which "works to expand and rejuvenate the ranks of the Jewish community by attracting young families." Another group with similar aims, active in Acre since 1997 is Garin Ometz ('seeds of courage') which, according to its website, includes about "200 young religious-nationalist families" (Garin Ometz, 2016). 


\subsection{Tourism and Displacement in the 'Diverse' City}

The post-colonial lexicon of 'multiculturalism' and 'mixed cities' has been used by Acre's leaders involved with tourism development since the first years following the 1948 war. For example, Yosef Gadish (Acre's mayor between 1952 and 1961) initiated an Arab minority folklore museum in the historical Ottoman hammam. Despite the displacement of most of Acre's residents a few years earlier in 1948 and the hazardous status of the Old City, for the mayor, the exhibit symbolised "the peaceful life that survives in our mixed city, Acre" (Torstrick, 2000, p. 68).

In the last decade, the development of a new municipal branding strategy has passed from officials in the municipality to an Israeli branding firm. This new actor maintained the discourse of 'diversity,' as they came up with the slogan 'Acre: City of Mediterranean cultures.' At the time, the slogan was not followed by immediate tourism activities (interview with Ketter, a consultant on tourism in Acre, in 2019; see also Avraham \& Ketter, 2015). It seems, however, that this exercise has forced decision-makers to re-consider the tourism potential of the city. In fact, Mayor Lancry dates his interest in pushing forward the 'Mediterranean Cultures' of the city to the intercommunity riots of Yom Kippur/Ramadan between 8 to 13 October 2008, during which tens of Jewish residents surrounded and attacked the house of a Palestinian who drove his car on the day of atonement, or 'Yom Kippur.' This developed into four days of riots involving thousands of Jewish and Palestinian residents and resulting in damaged houses and cars as well as tens of injured and arrested people. These events form the epitome of a series of attacks on Arabs and their properties in Acre, which increased in the previous years following the settlement of what is referred to as "Zionist settler groups" including the abovementioned Garin groups in the city (Arabs48, 2010). Nevertheless, following these violent events, the mayor argues: "We took the story of the Jews/Arabs [relations] as a lever. People hide multiculturalism. We took this multiculturalism and we put it on the priorities of every place" (interview with Mayor Lancry, 2014). To illustrate the municipal will, we were handed a book of stories and recipes of Acre's residents, from various national backgrounds, illustrating the many social groups present in the city, beside the general Palestinian/Jewish residents divide line. In a second interview, a year later, the mayor reaffirms: "Mediterranean cultures. That's the multicultural: tolerance....We knew that from the beginning, before the riots, we said that instead of looking at that as a weakness, look at it as an advantage, because, in Acre city, everybody lives! The city of everyone."

Unlike Zion's statements of "life or death," the mayor argues that "in Acre city, everybody lives," referring to immigrants and Palestinians as a multicultural society. These seemingly contradictory declarations represent two methods leading to the same aim: marginalising the
Palestinian identity of Acre and displacing the Palestinian population, or at least turning them into 'another' minority in the city. As to the existence of this multiculturalism, Nasreen, a 32-year-old Palestinian woman, said: "Although an increasing number of Palestinian families are living in the 'new' quarters, this has not led to coexistence: each group leads a separate life. Furthermore, the Palestinians are still suffering from racism." Similar opinions to these were reported by a survey conducted by Falah et al. (2000, p. 790), according to which Palestinians feel that not only do official institutions not promote coexistence between Jews and Palestinians, but they deliberately encourage residential segregation on ethnic grounds. Hence, they argue: "It is not surprising, thus, to find that [in] Acre the percentage of the Arab population has declined between 1961 and 1994" (Falah et al., 2000, p. 790).

Nevertheless, the neoliberal means of branding the city continue, as well as the exploitation of Palestinian existence for profit. In 2015, two experts based at Haifa University, Avraham and Ketter, proposed a new branding strategy for Acre "as a shared space between Arabs and Jews, and as an extension to the existing branding plan of Acre as a hub of Mediterranean cultures" (Avraham \& Ketter, 2015, p. 49). Meanwhile, the municipality's website still brings forth "Acre: City of Mediterranean cultures." This informs their tourism offer, with a focus on the Crusaders, Ottoman, and Jewish periods, with an absence of Palestinian history (Shoval, 2013). A tourism map of the city is available in different locations of the city, 22 out of the 35 sites indicated on the map being labelled 'Jewish sites.' Aside from municipal actors and external consultants, the term 'Mediterranean' also appears in tourism marketing materials, published by private actors, for example by Time Out magazine (2020).

However, the issues raised by Mayor Lancry regarding 'intercommunity' conflicts are far from being resolved through a new city branding. As Nasreen (2019) stated:

it's not just another Middle-Eastern or Mediterranean town-definitely not-it is a Palestinian town, and that is the part being erased when you promote it as Mediterranean, as if Middle-Eastern is a euphemism just to not say Palestinian; and it makes it sexier also, it makes it more exotic.

The struggle over these symbolic erasures goes back to the early years of the state. For instance, some planners suggested to turn the old city of Acre into an open museum, yet devoid of its Palestinian past (Paz, 1998, p. 124). In this regard, Slyomovics (2014) and Wolfe (2006, p. 389) argue that settler colonialism not only entitles the replacement of the native society by settlers, but also the use of their imprint. In the case of Acre, this can be reflected in the narratives attached to the landmarks, which are devoid of the Arab past (Shoval, 
2013), but it can also be traced in a double movement. On the one hand, as Bilal (2019) claimed, Jews who move into the Old city act as 'mistaarvim' ('Arabs in disguise'): "They 'reincarnate' the place, live in old Acre, go everywhere daily, go to the fishery." On the other hand, many 'Israelisation' policies are imposed on Palestinians, including civil service or the need of Hebrew language.

\subsection{Gentrification and Privatisation: New Means to Displace the Natives}

The implications of immigration policies and neoliberal practices are most evident on the ground, where noninstitutionalised actors are involved, such as immigrant investors. One such practice is the gentrification of indigenous neighbourhoods (Blomley, 2004; Coulthard, 2014). In the case of old Acre, processes of urban renewal and privatisation have relentlessly taken place over the last few decades.

While the historical sites had been given special attention since the 1950s, aiming to turn them into touristic attractions, the rest of the buildings that belonged to Palestinian refugees were neglected. Amidar, the governmental managing company, did not renovate the houses, banned new construction, and neglected the infrastructure, all conspiring to convert the neighbourhood into a slum area and to collapse some of the buildings (Torstrick, 2000, p. 67). Jews who moved to the quarter in the decades following 1948 left it during the 1960s as they were offered alternative housing in new neighbourhoods. This neglect began to lessen in the last two decades: Amidar started renovating houses and offering them for sale. The majority of the Palestinian residents were not able to buy the houses they lived in. Moreover, many were not able to pay their shares for the sudden sizable renovations made by Amidar, hence leading to hundreds of eviction orders and to a popular campaign "My house is not for sale" (Kurts, 2011). In a parliament committee meeting on November $18^{\text {th }}$, 2013, Haneen Zobi, a Knesset (Israeli Parliament) member affiliated to the Arab Party Balad, argued that the recent change is not part of a touristic project for developing the quarter for the benefit of the residents as Acre municipality claims, but is rather a long-term plan that aims to displace the Palestinian inhabitants. She argued: "In the 1970s, 8,000 residents lived there. Today, after 40 years, despite the natural increase, 3,000-4,000 people live there. This is a cleansing" (Knesset Economic Committee, 2013).

Meanwhile, in the city council, they insist that the last years' changes are an opportunity to open touristic businesses for Palestinians as well. The Head of Municipal Administration argued that for some projects "their aim is to preserve the soul of authentic Acre," and that the residents are part of these development processes. Yet, the question itself raises concerns regarding the role of the Palestinians in such plans. During our fieldwork in old Acre, Palestinian hostel owners expressed doubt- ful stands regarding the development processes. One owner was very hesitant to talk to us about 'politics,' yet, he said that Palestinian hostel owners are always treated as second class: "We [Palestinian businesses] are not their target audience in these development plans" (2019). Another Palestinian hostel owner shared with us his very long legal battle against Amidar and Old Acre Development Company to add another floor to a building he owns. He pointed out the discriminating approach these companies have regarding the ethnicity and political views of the owners: "You need to be Jewish or at least have strong links [with people in the municipality/Old Acre Development Company]" (2019). He also mentioned some rich Jewish investors who already own some assets in old Acre and who proposed to buy his hostel several times: "They want us to get exhausted, so we eventually sell the place." On the side of the street stands a new hostel owned by a Jewish investor from outside Acre. The place is designed as a capsule/pod hostel and offers, in the words of the receptionist at the hostel, a "traditional Arab floor seating." He commented on the fact that the owner is Jewish from outside Acre: "Sometimes you need people from outside to appreciate the beauty of the place," he said. One of our interviewees commented on the current situation saying that Palestinians in the new plans ought to either be displaced or, if they stay, form a silenced decoration: a reminder of Gadish's initiative for the Arab minority folklore museum. Bilal adds that misrepresentations go hand in hand with entrapment:

Most of the Palestinian fishermen and the restaurants are unlicensed/unauthorised. This is how the authorities can stop them whenever they want....Also, there is an employment problem and many Palestinians work in Israeli businesses. This situation makes us financially trapped and, hence, unable to express our opinion regarding what is happening in the city. (2019)

He emphasised that the "privatisation" policies are not only being employed to the refugees' houses, but also public places. Mentioning the UNESCO World Heritage Site "Caravanserail of the Pillars," built in 1784 and used in different periods, he said:

Khan al-Umdan is one of the places that was sold in a tender to French Jews; it is one of the city's historical landmarks. 15 years ago, it was a space used for shows by local Palestinian art groups, and sometimes we used to play football there.

A similar case is that of the luxurious Efendi boutique hotel. The receptionist argued it was a ruin and an abandoned building before today's owner, Uri 'Buri' Jeremias, "discovered it." It is worth mentioning here that in Israel, Uri Buri epitomises Acre for its seafood restaurants and cookbooks. The historical remains that the 
building contains-an Ottoman Hamam, Byzantine remnants, and Crusader cellars-became part of the hotel's facilities, accessible only to the wealthy consumers of the hotel. Bilal explained that behind the hotel's launch, a process of displacement took place in the neighbourhood, this included police harassment and surveillance mechanisms against the residents, to force them to leave. He argues that what the residents went through might look like gentrification, a process where veteran inhabitants are forced to leave and a strong population is encouraged to settle in; however, he explains this is not the case, but rather the continuation of the displacement policies of the locals by Jewish immigrants. He says that unlike gentrification, "what we [Palestinians] are facing is a long-lasting systematic dispossession."

\section{Discussion and Conclusions}

In this article, we have attempted to trace the institutional and noninstitutional actors as well as their macro and micro discourses: Approaching the intersection of migration, neoliberalism, and place-making from the settler-colonial framework revealed new forms and performances of the violent structures against the natives. Neoliberalism has created a new constellation of actors, organised along new structures, leading to a lesser presence of the government, but increased governmentality, in the Foucauldian sense of the term. Migration and urban development matters have moved further away from the central administration to be taken over by the municipality on the one hand, and by private actors on the other hand, including external consultants (Israeli branding firm, researchers), para-public bodies (Jewish Agency, the development authority, Amidar, 'Custodian of Absentees' Property,' the police, and more), non-profit organisations (Shavei Israel), messianic settlers (Garin Torani), as well as entrepreneurs (hotel industry, real estate, local media). Nonetheless, these new actors continue the settler-colonial strategies, such as using Palestinian heritage to give themselves a 'sense of nativeness' in parallel to portraying Palestinians as a rootless "silent decoration."

The mapping of actors informs us greatly on the normalisation of settler colonialism in the neoliberal era. This was enabled through a methodology focusing on the urban, a shifting of the gaze between national official ideology and urban practical techniques. Here again, actually existing neoliberalism(s)-that is, more concrete (local) forms of neoliberalism(s) (Brenner, Peck, \& Theodore, 2010; Peck \& Tickell, 2002)-work hand in hand with neoliberal performances of the violent structures against the natives in settler colonialism (Blomley, 2004; Coulthard, 2014). Under neoliberalisation, the settler-colonial structure sustains a series of small, noncentralised moves and discretionary acts, performed by a wide range of actors in various institutions impacting urban development that ultimately lead to displacement. Moreover, we argue that such an exploration must stem from the historical and political context of the place.

This conclusion is based on the observation of the historical place production in Acre: it starts with the dispossession of property and containment of the Palestinian residents in the Old City, to the management of properties by Amidar. It extends to developmentrelated tourism activities, where Jewish heritage is forced through on the one hand, while Palestinian historical places and Palestinian 'folklore' is used for economic purposes on the other hand. It is discursively performed through the branding of Acre as a 'city of Mediterranean cultures.' Hence, the Mediterranean imaginary also includes symbolic erasure, where natives are represented as "rootless" by colonial settlers (Wolfe, 2006). Through "narrative transfer" (Veracini, 2010, p. 182), indigenous people are represented as hopelessly backward, their identity being marginalised through Israelisation policies and their history being erased from narratives so that the actual society is defined as post-colonial (rather than colonial). While officials and agents at city hall argue that the qualification of "city of Mediterranean cultures" enables balancing the cultural and economic contributions of all socioethnic groups living in Acre, de facto, it reduces the Palestinian history and presence to a mere obstacle in a process where the ultimate goal stated is economic growth. Through globalised immigration policies, gentrification, and other neoliberal policies, indigenous spaces in the city become once again a 'frontier' for dispossession and displacement of the natives (Blomley, 2004; Coulthard, 2014; Sa'di-Ibraheem, 2020). Along with the symbolic erasure, an actual displacement of the natives occurs, for behind the globalised discourse on immigration and place-making, Palestinian existence translates to a "matter of life or death" and hence, as stated by the deputy mayor, Jewish immigration is a "blood transfusion." Therefore, the 'progressive' critical discourse on immigration and placemaking becomes in a settlercolonial society a justification and a means to carry out the elimination of natives in a 'legitimate' manner.

These findings corroborate and extend the growing literature on the politics of 'recognition' and 'multiculturalism' in settler-colonial states such as Canada, Australia, and the US in the neoliberal era. Moreover, it contributes to revealing the colonial agenda which is hidden behind the democratic, global, and progressive discourse of these regimes. Nevertheless, the processes described in this article are not only neutralised by the municipality and private actors but also through academic categorisations. Such academic discourses are not only prevalent in Israeli academia but also globally, as Jewish immigration to Israel is often entitled in academic conferences and journals as part of immigration studies and explored through analytical tools, which are relevant to the European reality. Within the politics of knowledge, we see a connection between policies and academic research: Who can be an immigrant? Who 
can be an entrepreneur? When are planning issues considered as individual matters versus collective concern? How are economic performances used to shadow colonial entailments? Thus, we hope that this contribution can modestly work towards a rethinking of globalised trends, even progressive and critical approaches, especially when discussing non-European native geographies and colonised spaces.

\section{Acknowledgments}

The research projects leading to this article were funded by the European Union's Seventh Framework Programme (FP7/2007-2013) under grant agreement No. 316796; the European Union's Horizon 2020 research and innovation programme under the Marie Sklodowska-Curie grant agreement No. 794030. We are also grateful to the interviewees who were willing to share their opinions and experiences with us. We also thank Ronen Ben-Arie and Layan AsSayed for their comments on an earlier version of this article, as well as to the anonymous reviewers for their constructive feedback. The authors have contributed equally.

\section{Conflict of Interests}

The authors declare no conflict of interests.

\section{References}

Abbasi, M. (2010). The fall of Acre in the 1948 Palestine War. Journal of Palestine Studies, 39(4), 6-27.

Amit, K. (2009). Determinants of life satisfaction among immigrants from Western countries and from the FSU in Israel. Social Indicators Research, 96(3), 515-534. https://doi.org/10.1007/s11205-0099490-1

Amoruso, F., Pappé, I., \& Richter-Devroe, S. (2019). Introduction: Knowledge, power, and the "settler colonial turn" in Palestine studies. Interventions, 21(4), 451-463.

Arabs48. (2010). Tishren alawal 2008 fe A'ka: tasalsol alahdas [October 2008 in Acre: The sequence of events]. Arabs48. Retrieved from https:// www.arab48.com/2010/10/

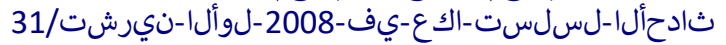

Auerbach, G. (2011). Local autonomy in action: Mobile homes for immigrants in Israel. Applied Geography, 31(2), 556-563. https://doi.org/10.1016/j.apgeog. 2010.11.009

Avraham, E., \& Ketter, E. (2015). Branding Acre city as a shared space. Haifa: University of Haifa.

Babis, D. (2016). The paradox of integration and isolation within immigrant organisations: The case of a Latin American association in Israel. Journal of Ethnic and Migration Studies, 42(13), 2226-2243.

Berthomière, W. (2003). "Le retour du nombre": Permanences et limites de la stratégie territoriale israélienne [The return of the number: Permanence and limits of the Israeli territorial strategy]. Revue européenne des migrations internationales, 19(3), 73-93. https://doi.org/10.4000/remi.475

Blomley, N. K. (2004). Unsettling the city: Urban land and the politics of property. New York, NY: Routledge.

Brenner, N. (2010). The urban question and the scale question: Some conceptual clarifications. In N. Glick Schiller \& A. Çağlar (Eds.), Locating migration: Rescaling cities and migrants (pp. 23-41). Ithaca, NY: Cornell University Press.

Central Bureau of Statistics. (2012). Immigrants, by age and first locality of residence in Israel. Jerusalem: Central Bureau of Statistics.

Central Bureau of Statistics. (2015). Peripherality index of localities and local authorities. Jerusalem: Central Bureau of Statistics.

Charmaz, K. (2011). Grounded theory methods in social justice research. In N. K. Denzin \& Y. S. Lincoln (Eds.), Strategies of qualitative inquiry (pp. 359-380). London: Sage Publications.

Chetrit, S. S. (2000). Mizrahi politics in Israel: Between integration and alternative. Journal of Palestine Studies, 29(4), 51-65. https://doi.org/10.2307/2676561

Coulthard, G. S. (2014). Red skin, white masks: Rejecting the colonial politics of recognition. Minneapolis, MN: University of Minnesota Press.

Desille, A. (2019). Jewish immigrants in Israel: Disintegration within integration? In S. Hinger \& R. Schweitzer (Eds.), Politics of (dis)Integration (pp. 141-159). Cham: Springer.

Dorchin, U., \& Djerrahian, G. (Eds.). (2020). Blackness in Israel: Rethinking racial boundaries. London: Routledge.

Elias, N., \& Kemp, A. (2010). The new second generation: Non-Jewish Olim, black Jews and children of migrant workers in Israel. Israel Studies, 15(1), 73-94.

Ellis, M. (2006). Unsettling immigrant geographies: US immigration and the politics of scale. Tijdschrift Voor Economische En Sociale Geografie, 97(1), 49-58. https://doi.org/10.1111/j.1467-9663.2006.00495.x

Falah, G., Hoy, M., \& Sarker, R. (2000). Co-existence in selected mixed Arab-Jewish cities in Israel: By choice or by default? Urban Studies, 37(4), 775-796.

Fenster, T. (2019). Creative destruction in urban planning procedures: The language of 'renewal' and 'exploitation' ${ }^{21}$. Urban Geography, 40(1), 37-57.

Fischbach, M. R. (2003). Records of dispossession: Palestinian refugee property and the Arab-Israeli conflict. New York, NY: Columbia University Press.

Garin Ometz. (2016). Homepage. OMETZ. Retrieved from http://www.ometz.org

Glaser, B., \& Strauss, A. (1967). The discovery of grounded theory: Strategies for qualitative research. Chicago, IL: Aldine.

Glick Schiller, N., \& Çağlar, A. (2010). Locating migration: Rescaling cities and migrants. Ithaca, NY: Cornell University Press. 
Golden, D. (2001). Storytelling the future: Israelis, immigrants and the imagining of community. Anthropological Quarterly, 75(1), 7-35.

Haberfeld, Y., Semyonov, M., \& Cohen, Y. (2000). Ethnicity and labour market performance among recent immigrants from the Former Soviet Union to Israel. European Sociological Review, 16(3), 287-299. https://doi.org/10.1093/esr/16.3.287

Hugill, D. (2017). What is a settler-colonial city? Geography Compass, 11(5), e12315.

Khalidi, R. I. (1992). Observations on the right of return. Journal of Palestine Studies, 21(2), 29-40.

Knesset Economic Committee. (2013). Putting Khan alUmdan up for sale to private parties through a tender by the Israel Land Authority (Archives of Minutes of parliamentary committees discussions held on 18 November 2013). Jerusalem, Israel.

Kurts, A. (2011). Yafo? Akko? [Jaffa? Acre?]. Calcalist. Retrieved from https://www.calcalist.co.il/local/ articles/0,7340, L-3519680,00.html

Lacroix, T. (2018). Le transnationalisme: Espace, temps, politique [Transnationalism: Space, time, politics]. Paris: Université de Paris Est.

Lahav, G. (1998). Immigration and the state: The devolution and privatisation of immigration control in the EU. Journal of Ethnic and Migration Studies, 24(4), 675-694.

Lerner, J. (2015). "Russe" dans l'État juif: Le sang, l'identité et l'administration nationale ["Russian" in the Jewish State: Blood, identity and national bureaucracy]. Ethnologie française, 45(2), 363-374. https:// doi.org/10.3917/ethn.152.0363

Lewin-Epstein, N., Semyonov, M., Kogan, I., \& Wanner, R. (2003). Institutional structure and immigrant integration: A comparative study of immigrants' labor market attainment in Canada and Israel. International Migration Review, 37(2), 389-420.

Lipshitz, G. (1998). Country on the move: Migration to and within Israel, 1948-1995. Cham: Springer.

Mesch, G. S. (2002). Between spatial and social segregation among immigrants: The case of immigrants from the FSU in Israel. International Migration Review, 36(3), 912-934. https://doi.org/10.1111/ j.1747-7379.2002.tb00109.x

Oomen, B. (2019). Decoupling and teaming up: The rise and proliferation of transnational municipal networks in the field of migration. International Migration Review, 54(3), 913-939. https://doi.org/ 10.1177/0197918319881118

Paz, Y. (1998). Shimur hamoreshet haadrichalit beschunot hanetushot le acher milchemet haatzmaut [Architectural preservation of abandoned neighborhoods during the aftermath of the war of independence]. Katedra, 88, 95-134.

Peck, J., \& Tickell, A. (2002). Neoliberalizing space. Antipode, 34(3), 380-404.

Porter, L., \& Yiftachel, O. (2019). Urbanizing settlercolonial studies: Introduction to the special issue. Set- tler Colonial Studies, 9(2), 177-186. https://doi.org/ 10.1080/2201473X.2017.1409394

Razin, E. (2003). Local government reform in Israel: Between centralization and decentralization, between traditionalism and modernity. Jerusalem: The Floersheimer Institute for Policy Studies.

Remennick, L. (2002). Transnational community in the making: Russian-Jewish immigrants of the 1990s in Israel. Journal of Ethnic and Migration Studies, 28(3), 515-530. https://doi.org/10.1080/136918 30220146581

Sa'di, A. H. (2016). Thorough surveillance: The genesis of Israeli policies of population management, surveillance and political control towards the Palestinian minority. Manchester: Manchester University Press.

Sa'di-lbraheem, Y. (2020). Privatizing the production of settler colonial landscapes: 'Authenticity' and imaginative geography in Wadi Al-Salib, Haifa. Environment and Planning C: Politics and Space. Advanced online publication. https://doi.org/10.1177/239965 4420946757

Samman, K. (2013). Zionism, the Occidentalization of the Jew, and the silencing of Palestinian history. Worlds and Knowledges Otherwise, 3(3).

Sayegh, F. A. (1965). Zionist colonialism in Palestine (Vol. 1). Beirut: Palestine Liberation Organization Research Center.

Scholten, P., \& Penninx, R. (2016). The multilevel governance of migration and integration. In B. GarcésMascareñas \& R. Penninx (Eds.), Integration processes and policies in Europe: Contexts, levels and actors (pp. 91-108). Cham: Springer. https://doi.org/ 10.1007/978-3-319-21674-4_6

Shavei Israel. (n.d.). Homepage. Shavei Israel. Retrieved from https://shavei.org

Shenhav, Y. A. (2006). The Arab Jews: A postcolonial reading of nationalism, religion, and ethnicity. Redwood City, CA: Stanford University Press.

Shilo, M. (1994). The Immigration Policy of the Zionist Institutions 1882-1914. Middle Eastern Studies, 30(3), 597-617.

Shoval, N. (2013). Street-naming, tourism development and cultural conflict: The case of the old city of Acre/Akko/Akka. Transactions of the Institute of British Geographers, 38(4), 612-626. https://doi.org/ 10.1111/tran.12003

Slyomovics, S. (2014). Who and what is native to Israel? On Marcel Janco's settler art and Jacqueline Shohet Kahanoff's "Levantinism." Settler Colonial Studies, 4(1), 27-47.

Svirsky, M., \& Ben-Arie, R. (2017). From shared life to co-resistance in historic Palestine. Lanham, MD: Rowman \& Littlefield.

Time Out. (2020). A tourist's guide to Akko: Where to eat, explore and sleep. Time Out. Retrieved from https://www.timeout.com/israel/things-to-do/atourists-guide-to-akko

Torstrick, R. L. (2000). The limits of coexistence: Identity 
politics in Israel. Ann Arbor, MI: University of Michigan Press.

Tubergen, F., Maas, I., \& Flap, H. (2004). The economic incorporation of immigrants in 18 Western societies: Origin, destination, and community effects. American Sociological Review, 69(5), 704-727.

Tzfadia, E. (2011). Mixed cities in Israel: Localities of contentions. Israel Studies Review, 26(1), 153-165.

Tzfadia, E., \& Yacobi, H. (2007). Identity, migration, and the city: Russian immigrants in contested urban space in Israel. Urban Geography, 28(5), 436-455. https://doi.org/10.2747/0272-3638.28.5.436

Tzfadia, E., \& Yacobi, H. (2011). Rethinking Israeli space: Periphery and identity. Abingdon: Taylor \& Francis.

Varsanyi, M. (2008). Rescaling the 'alien,' Rescaling personhood: Neoliberalism, immigration, and the state. Annals of the Association of American Geographers, 98(4), 877-896.

Veracini, L. (2010). Settler colonialism: A theoretical overview. New York, NY: Palgrave Macmillan.
Wolfe, P. (2006). Settler colonialism and the elimination of the native. Journal of Genocide Research, 8(4), 387-409.

Yacobi, H. (2009). The Jewish-Arab city: Spatio-politics in a mixed community (Vol. 5). London: Routledge.

Yacobi, H., \& Tzfadia, E. (2017). Neo-settler colonialism and the re-formation of territory: Privatization and nationalization in Israel. Mediterranean Politics, 24(1), 1-19. https://doi.org/10.1080/13629395. 2017.1371900

Yiftachel, O. (2000). 'Ethnocracy' and its discontents: Minorities, protests, and the Israeli polity. Critical Inquiry, 26(4), 725-756.

Yiftachel, O., \& Tzfadia, E. (2004). Between periphery and 'third space': Identity of Mizrahim in Israel's development towns. In A. Kemp, U. Ram, D. Newman, \& O. Yiftachel (Eds.), Israelis in conflict: Hegemonies, identities and challenges (pp. 203-235). Brighton: Sussex Academic Press.

\section{About the Authors}

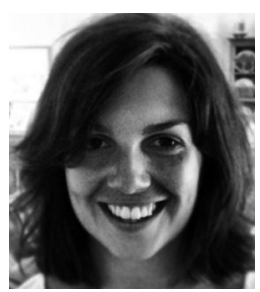

Amandine Desille is an MSCA Postdoctoral Fellow at the Institute of Geography and Spatial Planning at the University of Lisbon. She studies international migrations, return migrations, local governance, and ordinary cities. She co-authored the volume International Migrations and Local Governance: A Global Perspective, published at Palgrave Macmillan in 2018. Her research has also been published in Political Geography and GeoJournal, among others.

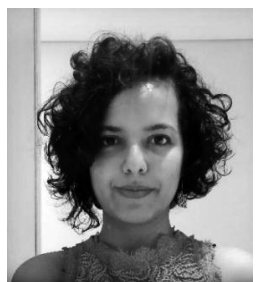

Yara Sa'di-Ibraheem is a PhD Student in the Department of Geography and Human Environment at Tel-Aviv University. Her fields of research include indigenous geographies, settler colonialism, neoliberal urbanism, and spatial-temporal experiences. Her work was published in Environment and Planning C: Politics and Space, Time \& Society, and GeoJournal, among others. 